\title{
EXPERIMENTAL STUDY ON EFFECT OF TREATED WATER ON THE MECHANICAL PROPERTIES OF CONCRETE
}

\author{
Dr. Shanthala B ${ }^{1}$, Mithesh Kumar ${ }^{2,}$ Jagadisha ${ }^{3}$ \\ 1,2,3 Assistant Professor, Department of Civil Engineering \\ Government Engineering College, Karwar, Karnataka.
}

\begin{abstract}
Now a days there is so much scarcity of water. That is there is need to arrange other sources ofwater for concrete or construction of building units. This portable water which now a days drain in river can use in concrete. Low cost and environment friendly concrete can be produced by using portable water inconcrete. Concrete cost can be reduced by using portable water that also provides green productions. The amount of water in concrete controls many fresh and hardened properties of concrete including workability, compressive strengths, permeability and water tightness, durability and weathering, drying shrinkage and potential for cracking. For these reasons, limiting and controlling the amount of water in concrete is important for both constructability and service life. In a present dailylife cement is a basic binding, indispensable materials mainly used for all the types of construction works such as high rise building, sleepers, dams, bridges, water tanks, cement concrete roads etc..., for all these types of work cement is used as a binding material, with the use of naturally occurring material such as lime and clay, cement is manufactured. While manufacturing of cement it releases carbon dioxide to the environment which causes environmental pollution problems. So waste utilization in cement \& concrete should be maximized to achieve cost reduction, saving in energy, resource conversation, improved production quality, environmental pollution, improves durability \& enhanced performance. The present work presents the use of treated waste water and potable water in concrete for bothmixing and curing. The M-20 grade concrete designed and compressive strength, tensile strength, flexural strength for 7, 14, 28 days are studied and compared with control mix.
\end{abstract}

Keywords: Concrete, Cement, Waste Water, Cracking, Compressive Strengths, Tensile strength

\section{INTRODUCTION}

Water is a transparent and nearly colourless chemical substance that is the main constituent of Earth's streams, lakes, and oceans, and the fluids of most living organisms. Its chemical formula is $\mathrm{H}_{2} \mathrm{O}$, meaning that its molecule contains one oxygen and two hydrogen atoms, that are connected by covalent bonds. Water strictly refers to the liquid state of that substance, that prevails at standard ambient temperature and pressure; but it often refers also to its solid state (ice) or its gaseous state (steam or water vapour). It also occurs in nature as snow, glaciers, ice packs and icebergs, clouds, fog, dew, aquifers, and atmospheric humidity.

Water covers $71 \%$ of the Earth's surface it is vital for all known forms of life. On Earth, 96.5\% of the planet's crust water is found in seas and oceans, $1.7 \%$ in groundwater, $1.7 \%$ in glaciers and the ice caps of Antarctica and Greenland, a small fraction in other large water bodies, and $0.001 \%$ in the air as vapour, clouds (formed of ice and liquid water suspended in air), and precipitation. Only $2.5 \%$ of this water is fresh water, and $98.8 \%$ of that water is in ice (excepting ice in clouds) and groundwater. Less than $0.3 \%$ of all freshwater is in rivers, lakes, and the atmosphere, and an even smaller amount of the Earth's freshwater $(0.003 \%)$ is contained within biological bodies and manufactured products. A greater quantity of water is found in the earth's interior. Water is usedfor,Agriculture,drinking, Washing,Transportation, Che micalses, Heatexchange, Recreation,Industries,Foodprocessi ng and for medical uses.

Clean, safe drinking water is scarce. Today, nearly 1 billion people in the developing world don't have access to it. Yet, we take it for granted, we waste it, and we even pay too much to drink it from little plastic bottles. Water is the foundation of life. And still today, all around the world, far too many people spend their entire day searching for it. In places like sub-Saharan Africa, time lost gathering water and suffering from water-borne diseases is limiting people's true potential, especially women andgirls.

Water scarcity is the lack of sufficient available water resources to meet water needs within a region. It affects every continent and around 2.8 billion people around the world at least one month out of every year. More than 1.2 billion people lack access to clean drinking water.

Water scarcity involves water shortage, water stress or deficits, and water crisis. The relatively new concept of water stress is difficulty in obtaining sources of fresh water for use during a period of time; it may result in further depletion and deterioration of available water resources. Water shortages may be caused by climate change, such as altered weather-patterns (including droughts or floods), increased pollution, and increased human demand and overuse of water. The term water crisis labels a situation where the available potable, unpolluted water within a region is less than that region's demand. Two converging phenomena drive water scarcity: growing freshwater use and depletion of usable freshwater resources. The problem of water scarcity is a growing one. As more people put ever-increasing demands on limited supplies, the cost and effort to build or even maintain access to water will increase. And water's importance to political and social stability will only grow with the crisis.

Concrete is second most water consumable industry in the world. As a sustainability approach and to overcome the scarcity of water we used treated waste water in concrete. Wastewater, also written as waste water, is any water that has been adversely affected in quality by anthropogenic influence. Wastewater can originate from a combination of domestic, industrial, commercial or agricultural activities, 
surface runoff or storm water, and from sewer inflow or infiltration.

Municipal wastewater (also called sewage) is usually conveyed in a combined sewer or sanitary sewer, and treated at a wastewater treatment plant. Treated wastewater is discharged into receiving water via an effluent pipe. Waste waters generated in areas without access to centralized sewer systems rely on on-site wastewater systems. These typically comprise a septic tank, drain field, and optionally an on-site treatment unit. The management of wastewater belongs to the overarching term sanitation, just like the management of human excreta, solid waste and storm water. We collected treated waste water from the treatment plant Nitte, Karkala.

Marcia Silva.Et.Al, (2008),In this paper "Sustainable Use of Resources - Recycling of Sewage Treatment Plant Water in Concrete", Concrete is the most widely used construction material in the world. Therefore, sustainability of the concrete industry is of societal importance. Production of Portland cement used in concrete produces over 2.5 billion tons of carbon dioxide $(\mathrm{CO} 2)$ and other green-house gases (GHGs) worldwide. In addition, concrete is one of the largest water consuming industries. This paper presents an overview of the current state of knowledge about the use of reclaimed water, especially partially processed sewage treatment plant water in concrete. These preliminary research findings suggested that significant differences do not exist between mortar cubes made of potable water versus sewage treatment plant water. Further research is needed because there is a strong need to manufacture concrete in a more sustainable manner. Some of the possible outcomes and contributions of this research are: to minimize the need for the use of potable water; eliminate the need to expand potable water supply for use in the concrete industry; minimize the need to construct more water treatment facilities due to population growth; save potable water for drinking purposes; make sewage treatment plants become more economically attractive by reusing water before its final treatment; and, other similar goals towards sustainable developments.

In this paper "Utilization of waste water to check strength parameter of the concrete", reviews the possibility of replacing fresh water with waste water for making concrete. The strength is not affected so much by using waste water as replacement for waste water. From the literature it is seen that, the reaction between waste water and cement affect the workability, compressive strength and flexural strength. The reduced strength is within the acceptable limit. The use of impure water for concrete mixing is reduces the cost of the construction and in this way the process of construction becomes economical. on replacement of fresh water with waste water (sewage water), found that on increasing the composition of waste water strengths (compressive, flexural) goes on decreasing with further increase in waste water composition. The slump values are found to be decreasing with the increase in the $\%$ of waste water.

VINUT KULKARNI et.al, (2014) In this paper "A Study on Compressive Strength of Concrete Using Treated Domestic Waste Water", in the present day there is a scarcity of fresh water and construction activities are increasing day by day consuming huge quantity of fresh water. Therefore, research is going on to use treated domestic waste water in the preparation of concrete. The concrete specimens prepared with M20 and M40 grade concrete. The concrete specimens cast by using $0 \%, 50 \%$, and $100 \%$ treated domestic wastewater and cured in treated domestic waste water for 7days 14days and 28days. Increase in compressive strength from 7 days to 14days for all the 4 mixes is marginal for both the grades of concrete i.e. M20 and M40. At 28days curing age decrease in compressive strength was observed from mix M1 to M4 expect mix M2. This decrease in compressive strength may be due the use of treated domestic waste water for mixing and curing. Lowest strength is exhibited by Mix M4 i.e. 28.77Mpa however this strength is higher than the target mean strength of 26. 4Mpa.The excess quantity of bicarbonates in treated domestic waste water as mixing water results decrease in compressive strength concrete specimens.

ESTUO SAKAI et.al, (2006)In this paper "New trends on the Development of Chemical Admixtures in Japan" describes the history and new trend in the development of chemical admixture in japan. PC (Polycarboxylic acid) based agent are the main product in the super plasticizer market. The flowing speed of concrete withlow stickiness type PC-based super plasticizer is faster than that with the conventional PC-based super plasticizer. The hydration of cement in sludge water is controlled by addition of a setretarder, and the specific surface area of cement does not increase while a large amount of unreacted alite remains insludge water.

Chemical admixtures such as air entraining (and high range) water reducing agents are used in most concretes in japan. Moreover, many type of admixture that provide the performance demanded by new construction technologies are in used such admixture are mainly used to improve the fluidity, to control setting or hardening times, and to reduce volume changes of concrete. The development of naphthalene-based-super plasticizers by Hattori in 1962 was an important event in the field of chemical admixture in japan. Chemical admixtures are necessary and indeed indispensable for adding new function to concrete. The long term durability of a concrete structure is important when aligned with a decrease in the amount of the construction investment. PC super plasticizer is necessary for such highly durable concrete. With PC- based super plasticizer, many types of polymers can be synthesized and new types PC- based super plasticizer can be supplied by reformulations of the polymers.

IBRAHIM AL- GHUSAIN et.al, (2003)In this paper "Use of Treated Waste Water for Concrete Mixing in Kuwait", he clearly explained about the type of water used for mixing did not affect to concrete slump and density. However, setting time were found to increase with deteriorating water quality. Preliminary treated waste water and secondary treated waste water were found to have the most effect on retarding setting time. This paper presents a study of the mechanical properties of concrete mixed using tap water, preliminary treated waste water, secondary treated waste water and tertiary treated waste water. In particular, the effect of water type on the following properties such as setting time and compressive strength is 
being studied. Both initial and final setting times were affected by the type of mixing water. The possibility for steel corrosion also increased with the use of treated.

\section{Materials}

\section{MATERIALS AND METHODS}

Cement: OPC 33 Grade cement is used and the properties are mentioned in Table 1

Table 1: Properties of Cement

\begin{tabular}{|l|l|}
\hline $\begin{array}{l}\text { Standard Consistency of Cement } \\
\text { Paste }\end{array}$ & $31 \%$ \\
\hline Initial Setting Time & 118 Mins \\
\hline Final Setting Tim & 236 Mins \\
\hline Specific Gravity & 3.12 \\
\hline
\end{tabular}

Fine Aggregate: Locally available natural sand is used as fine aggregate. The properties of fine aggregates are presented in Table 2.

Table 2: Properties of Fine Aggregate

\begin{tabular}{|l|l|}
\hline Parameter & Test Results \\
\hline Specific Gravity & 2.53 \\
\hline Bulk Density: & \\
Loose State $\mathrm{Kg} / \mathrm{m}^{3}$ & 1434.00 \\
Compacted $\mathrm{Kg} / \mathrm{m}^{3}$ & 1525.00 \\
\hline Silt Content & $0.38 \%$ \\
\hline Water absorption & $1.40 \%$ \\
\hline Bulking of Sand & $23 \%$ \\
\hline
\end{tabular}

CoarseAggregate: Locally available crushed angular $20 \mathrm{~mm}$ nominal size coarse aggregate was used. The properties of coarse aggregate were tested according to IS 383-1970 1970 (Reaffirmed 2011) with following properties.

Table 3: Properties of Coarse Aggregate

\begin{tabular}{|l|l|}
\hline Bullk density (Loose state) & $1408 \mathrm{~kg} / \mathrm{cu.m}$ \\
\hline $\begin{array}{l}\text { Bullk density (compacted } \\
\text { state) }\end{array}$ & $1639 \mathrm{~kg} / \mathrm{cu.m}$ \\
\hline Specific gravity & 2.63 \\
\hline Water absorption & $0.50 \%$ \\
\hline
\end{tabular}

Water: In the control mix the normal portable water and other mix treated waste water is used. The properties of treated water are presented in Table 4.

Table 4: Properties of Treated water

\begin{tabular}{|l|c|c|}
\hline \multicolumn{1}{|c|}{ Parameter } & $\begin{array}{c}\text { Treated waste } \\
\text { waterin } \\
\mathrm{mg} / 1\end{array}$ & $\begin{array}{c}\text { Permissible } \\
\text { limitin } \\
\mathrm{mg} / 1\end{array}$ \\
\hline $\mathrm{pH}$ & 7.39 & $>6$ \\
\hline $\mathrm{DO}$ & 5.4 & - \\
\hline $\mathrm{COD}$ & 48.95 & 3000 \\
\hline Chloridecontent & 56.78 & 2000 \\
\hline Acidity & 225 & 300 \\
\hline Alkalinity & 478 & $>200$ \\
\hline Sulphatec ontent & $\mathbf{8 7}$ & 400 \\
\hline Calcium con tent & 0.327 & $75-200$ \\
\hline Magnesiumcontent & 85 & $30-100$ \\
\hline $\begin{array}{l}\text { TotalhardnessasCa } \\
\text { CO3 }\end{array}$ & $485 \mu \mathrm{s}$ & - \\
\hline \begin{tabular}{l} 
Conductivitytest \\
\hline \multicolumn{1}{|c|}{ Aggregate }
\end{tabular} & 594 & 594 \\
\hline $\begin{array}{l}\text { Fine Aggregate } \\
\left(\mathrm{kg} / \mathrm{m}^{3} \text { ) }\right.\end{array}$ & 1210 & 1210 \\
\hline $\begin{array}{l}\text { Coarse } \\
\left(\mathrm{kg} / \mathrm{m}^{3} \text { ) }\right.\end{array}$ & & \\
\hline
\end{tabular}

Mix Design: The mix design is carried out as per IS-102622009 for M-20 concrete with water cement ratio 0.4

Testing of Specimens: Concrete is prepared for M-20 grade mix design and cured for 7,14, 28 days and compressive, flexural and tensile strength where studied.

Table 5: Mix Proportion

\begin{tabular}{|l|l|l|}
\hline & $\begin{array}{l}\text { Control Mix } \\
(\mathrm{CM})\end{array}$ & $\begin{array}{l}\text { Mix 1 } \\
(\mathrm{CM} 1)\end{array}$ \\
\hline $\begin{array}{l}\text { Water Cement } \\
\text { Ratio }\end{array}$ & 0.45 & 0.45 \\
\hline $\begin{array}{l}\text { Cement Content } \\
\left(\mathrm{kg} / \mathrm{m}^{3}\right)\end{array}$ & 355 & 355 \\
\hline Water $\left(\mathrm{kg} / \mathrm{m}^{3}\right)$ & 160 (Portable) & 160 (Treated Water) \\
\hline $\begin{array}{l}\text { Fine Aggregate } \\
\left(\mathrm{kg} / \mathrm{m}^{3}\right)\end{array}$ & 594 & 594 \\
\hline $\begin{array}{l}\text { Coarse } \\
\text { Aggregate }\end{array}$ & 1210 & 1210 \\
\hline
\end{tabular}

III.RESULTSANDDISCUSSION

\subsection{Compressive strength}

The compressive strength of portable water and treated water for 7, 14 and 28 days are presented in Figure 1.

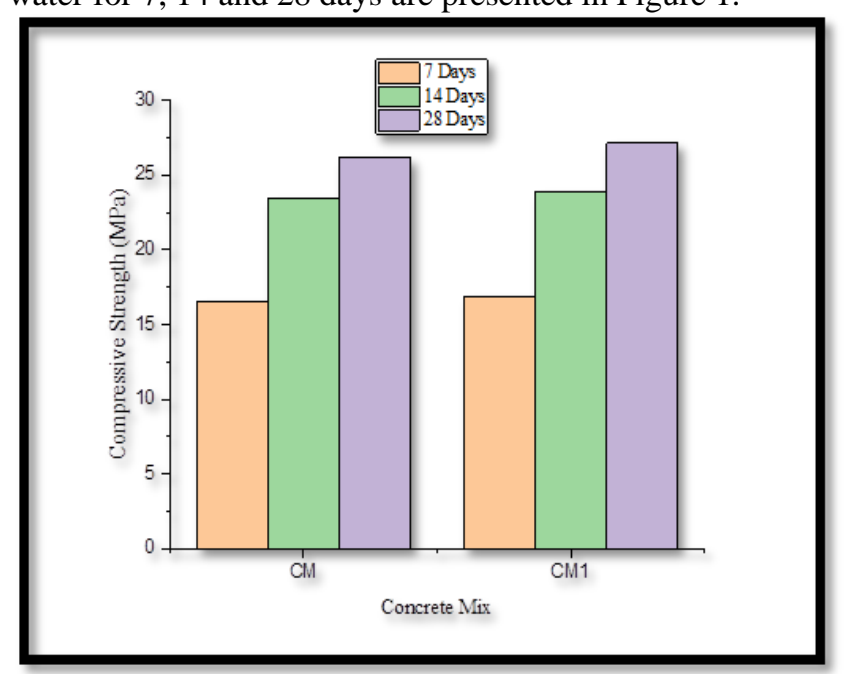

Figure 1: Compressive Strength of mixes at 7, $14 \& 28$ days

It is observed that both the mixes obtain mean target strength at 28 days. The compressive strength of $7.14 \& 28$ days of treated water sample is grater than the control mix. The similar trend was observed by earlier researcher. 


\subsection{Flexural strngth}

The flexural strength of concrete mix for 14 and 28 days are presnted in Figure 2. The flexural strength of both the mixes are with in the acceptable limit and higher value is observed with mix prpared and cured with treated water.

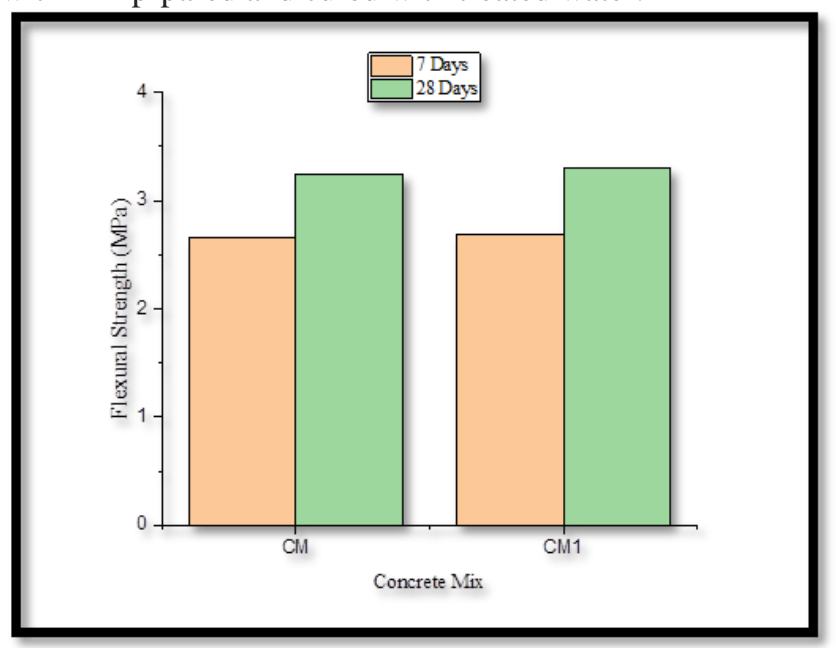

Figure 2: Flexural Strength of mixes at $7 \& 28$ days

\subsection{Tensile Strength:}

The Tensile strength of concrete mix for 14 and 28 days are presnted in Figure 3.The tensile strength of both the mixes are with in the acceptable limit and higher value is observed with mix prpared and cured with treated water.

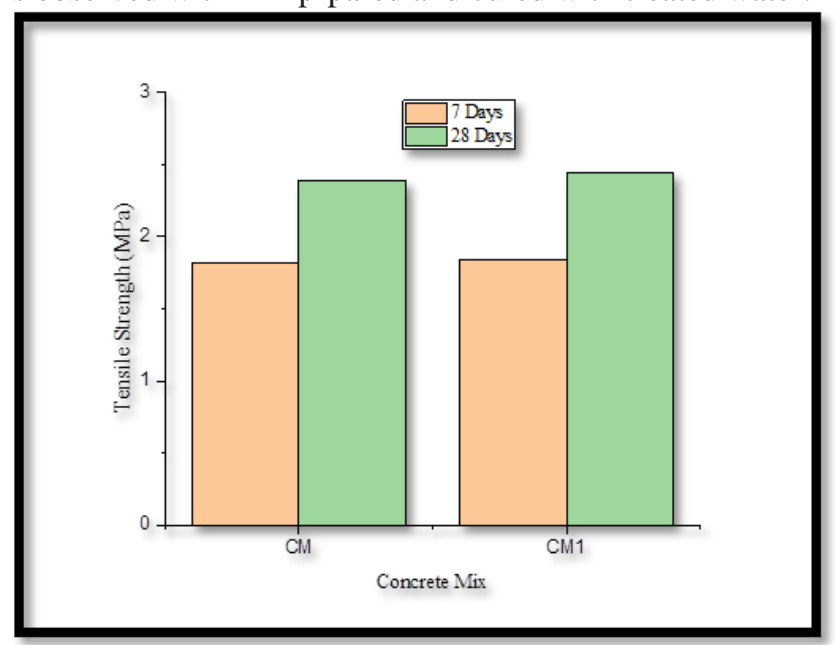

Figure 3: Tensile Strength of mixes at $7 \& 28$ days

\section{CONCLUSION}

Based on the experimental results the following conclusions were drawn, The both mixes obtained the mean target strength for M20 mix with the cement content $355 \mathrm{~kg} / \mathrm{m}^{3}$ and water cement ratio 0.45 , The compressive strength of mix cast and cured by treated waste water as obtain increase in strength of $1.22 \% \& 1.82 \%$ respectively for $7 \& 28$ days curing w.r.t control mix.The Flexural strength of mix cast and cured by treated waste water as obtain increase in strength of $1.22 \%, \& 1.82 \%$ respectively for $7 \& 28$ days curing w.r.t control mix.The split tensile strength of mix cast and cured by treated waste water as obtain increase in strength of $1.17 \% \& 2.06 \%$ respectively for $7 \& 28$-days curing w.r.t control mix.In the current study it is observed that strength achieved in treated waste water is increasing throughout the curing ages for compressive, flexural and tensile strength. The treated water sample is fall well with in the permissible limit and can be used for construction activities.From the current experimental work, we can conclude that we can effectively use treated waste water in construction activities.

\section{REFERENCES}

[1] Marcia Silva and Tarun R Naik "Sustainable Use Of Resources - Recycling Of Sewage Treatment Plant Water In Concrete".

[2] Ibrahim Al-Ghusain And Mohammad J.Terro "Use Of Portable Water For Concrete Mixing In Kuwait", Kuwait J.Sci.Eng.30 (1) 2003.

[3] Kishanlal Jain, Abhishek Kumar, Ankit Kumar, Ashok Kumar, Bhagirath Jat, and Abhinav Kumar "Utilization Of Waste Water To Check Strength Parameter Of The Concrete", Volume 3 Issue 7 - July 2016.

[4] Vinut Kulkarni and Suresh G Patil,“A Study On Compressive Strength Of Concrete Using Treated Domestic Waste Water", IJSRD - International Journal For Scientific Research \& Development Vol. 2, Issue 10, 2014.

[5] Estuo Sakai, Atsumu Ishida and Akira Ohta "New Trends In The Development Of Chemical.

[6] M S Shetty "Concrete Technology", S Chand and Company Ltd., 2012, 25 ${ }^{\text {th }}$ edition. 